\section{Paul Smith}

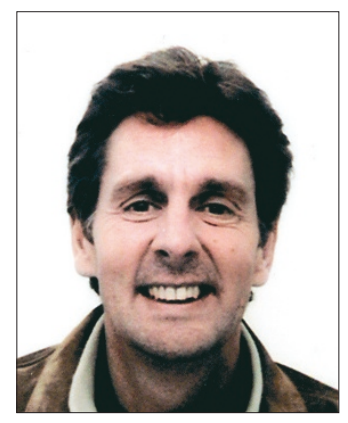

Paul Smith was in his 50th year when he was tragically killed in a motorcycle accident. Born 18th December 1952 and brought up in Finchley, North London, he attended Christ College Grammar School before studying dentistry at UCH. He was a gifted football player and had a deep love for the game, being a lifelong Gunner supporter and holding a season ticket. Paul played for Middlesex Schools and London University before a knee injury curtailed his playing career. When England won the World Cup at Wembley, Paul was a ball boy but he had to run out on to the pitch in a West German strip!

Paul's interest in orthodontics was kindled when he received treatment at UCH. This was carried out by a dental student called Derek Willmott, under the supervision of Professor Jim Moss. With Jim Moss's advice Paul applied to UCH to study dentistry. Once qualified Paul worked initially at Clive Lewis's practice in Burnt Oak and subsequently Henry Arnold's practice in Fleet Street before deciding that he would be happiest in the speciality. A short spell of working in an orthodontic practice in Oxford confirmed this and he gained a place at UCH as registrar, where by now Derek was senior registrar. During his postgraduate training Paul supported his family by working weekends, evenings and holidays in general dental practice.

After passing the DOrth. Paul worked in Reading in David Beckett's practice confirming his reputation for being a charming man with great skills as an operator. His patients, his staff and colleagues found him to be amusing, debonair and fun loving, always with a mischievous twinkle in his eyes.

He started his own practice initially at home in Pinner before moving it to Harrow where it thrived. He took over and built up Joan Ritchie's practice in London's Cavendish Square. He also found time

\section{His patients, his staff and colleagues found him to be amusing, debonair and fun loving, always with a mischievous twinkle in his eyes.}

to be a magistrate. Instead of football Paul was now playing tennis, always competitively. In recent years Paul took up mountaineering, this was to combat his fear of heights! Having climbed in Ecuador and the Scottish Highlands, he was planning a trip to the Himalayas. Paul loved speed and thrills, this came out in his choice of fast cars and motorbikes as his mode of transport.

Paul was the galvanising force in setting up an orthodontic visiting programme to the National Dental Hospital in Cambodia. Being fluent in French and never taking no for an answer he has over the last year made two visits to Phnom Penh and has enlisted Professor Moss to be one of the visiting lecturers.

From an early age Paul was a deeply committed Christian. He helped teach the younger members at his family church and was the warden at Emmanuelle Church in Northwood where over 600 people attended his memorial service. He would have had no fears about dying, it is the people that knew and loved him that have been hurt by his early departure. All who met Paul said, "He was my best friend".

Paul leaves a beautiful wife Francine, daughter Charlotte (a law student at Exeter University), son Jonathan (a commercial airline pilot), sister Alison and mother and father Una and Harold.

For further information on the Cambodia Project please contact john.hammond@lpct.scot.nhs.uk. Anyonewishing to make a donation in memory of Paul should send a cheque payable to: SAO Cambodia via Francine Smith, 12 Bedford Rd Moor Park Middx HA6 2AZ.

Stewart Hawthorn

\section{George Alfred Elliott}

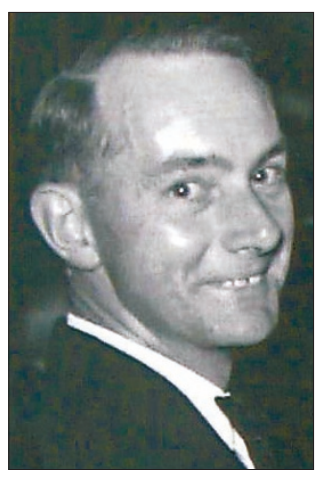

George Alfred Elliott LDS died peacefully at his home on 18th June 2003 after a short illness. George was born in Shrewsbury in 1910. Being the son of the manager of Shrewsbury gasworks nearly led him into a career in engineering; his one time ambition was to be a locomotive design engineer.

But in 1928 his manual creativity led him to train as a dental mechanic. His flair for doing things with his hands led him to commence studies at Birmingham Dental School in 1931. Whilst there he won the James Youngson Memorial Prize in Dental Prosthetics and the Bronze Medal for Conservative Dentistry. George qualified in 1935 and entered general practice in Shrewsbury. During the war years he served in the School Dental Service in Breconshire in particular treating large numbers of evacuee children.

At the end of hostilities he established a practice in Teignmouth Devon. A well-earned retirement commenced in 1971, which allowed him to devote more time to his favourite pastimes, model engineering and fishing. Although this obituary is

\section{Being the son of the manager of} Shrewsbury gasworks nearly led him into a career in engineering; his one time

\section{ambition was to be a locomotive design engineer.}

very brief, he was a modest man and would prefer it that way. He is sadly missed by his wife Freda, daughter Judith and son Clive who is himself in dental practice in Winchester.

Clive Elliott

\section{David Poswillo CBE}

There will be a memorial service for Professor David Poswillo at GKT Dental Institute, Guy's Hospital Chapel, London, on Thursday 16th October 2003 at $11.00 \mathrm{am}$ followed by a reception in Atrium 1 at 12.00 noon. RSVP Mrs Sandi 02079554342. 